\title{
DETERMINASI PERTUMBUHAN EKONOMI BERKELANJUTAN DI ASEAN-3
}

\author{
Soeharjoto Soekapdjo ${ }^{1}$, Astrid Maria Esther ${ }^{2}$ \\ ${ }^{1,2}$ Fakultas Ekonomi dan Bisnis, Universitas Trisakti \\ Jl. Jl. Kyai Tapa No.1 Jakarta Barat \\ Email: ryoto16@yahoo.com \\ diterima: 18/7/2019; direvisi: 24/8/2019; diterbitkan: 24/9/2019
}

\begin{abstract}
Aim of this study is about sustainable economic growth determination in ASEAN-3 from 2000-2016. Using regression with panel data, and as dependent variable is GDP per capita, inflation, capital formation, population, total savings, and depletion of natural resources as a independent variables. Result shown that capital formation, total savings has a significant and positive effect to GDP per capita, while depletion of natural resources, inflation and population has significant and negative effect. Restructuring is needed to improve efficiency, quality of human resources, attractiveness of investment and savings, anticipation of macroeconomic turn oil, co-operations between ASEAN members and non members to maintain sustainable economic growth.
\end{abstract}

Keywords: Sustainable economic growth, ASEAN-3, GDP per capital, inflation, capital formation, population, total savings, depletion of natural resources

\section{PENDAHULUAN}

Negara-negara di Asia Tenggara dalam menghadapi era globalisasi, pada bidang politik dan ekonomi kawasan, membentuk ASEAN Community. Komunitas ini, menggunakan pendekatan ekonomi, polkam, dan sosbud (Gunadi, 2016). Untuk pilar ekonomi, dibentuk ASEAN Economic Community (AEC), yang bertujuan membentuk pasar tunggal ASEAN. Adapun harapannya, agar dapat meningkatkan daya saing ekonomi (Soeharjoto, 2016).

Keberhasilan pembangunan negara, tercermin dari pertumbuhan ekonominya (Soeharjoto, 2018). Hal ini, juga yang terjadi pada ASEAN yang terbentuk di 1967, dengan anggota sebanyak lima negara dan kini sudah menjadi sepuluh negara. Namun, dari beberapa negara yang tergabung dengan ASEAN, terdapat tiga negara dengan kriteria sama, yang memiliki kekayaan sumber daya alam dengan middle income. Adapun ketiga negara tersebut meliputi Malaysia, Indonesia, dan Filipina.
Pasar tenaga kerja dari ketiga negara ASEAN, memiliki kondisi yang beragam, dengan kemudahan mencari tenaga kerja terampil yang menggunakan skala 1-7, di Malaysia sebesar 5,3 dengan average income bulanan 609 USD, Filipina sebesar 4,4 dengan average income bulanan 206 USD dan Indonesia sebesar 4,3 dengan average income bulanan 174 USD (www3.weforum.org). Kondisi tersebut, sesuai dengan Human Capital Index ASEAN pada 2016, yang memiliki peringkat global ke 43 dengan skor 74,28 di Malaysia, peringkat global ke 49 dengan skor 71,75 di Filipina, dan peringkat global ke 72 dengan skor 67,61 di Indonesia. Global Competitiveness Index di tiga negara ASEAN, Malaysia mempunyai daya saing paling tinggi, kemudian Indonesia dan Filipina (Gambar 1). 


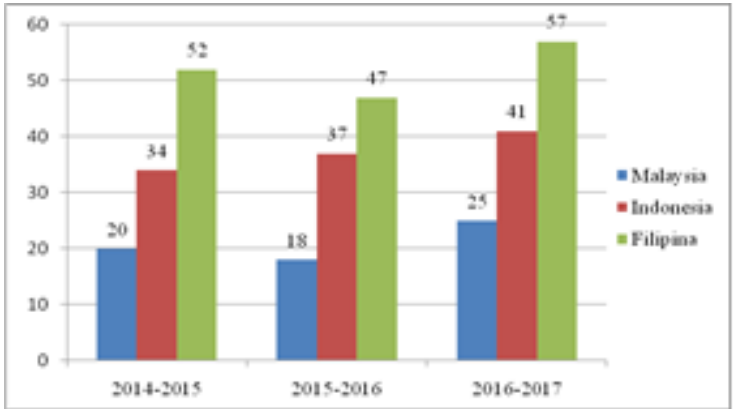

Gambar 1. Global Competitiveness Index di Tiga Negara ASEAN

Sumber: www. World Economic Forum

Fenomena krisis multidemensi terbaru, telah mempengaruhi sebagian besar negara di berbagai belahan dunia (Schembri, 2015). Keadaan ini, diperkuat dengan adanya degradasi kondisi dari tenaga kerja dan adanya fregmentasi sosial. Kesemuanya, menjadi tantangan bagi negara untuk dapat lebih fokus pada pembangunan berkelanjutan, dengan mempromosikan pertumbuhan hijau (low carboneconomy). Adapun konsekuensinya akan terjadi transformasi besar terhadap revolusi industri, dengan tetap memperhatikan kualitas hidup.

Pertumbuhan ekonomi diperlukan untuk menunjang kesejahteraan masyarakat ASEAN-3. Peningkatan pertumbuhan ekonomi yang tidak menunjang kelestarian lingkungan, justru akan semakin membuat masyarakat jauh dari harapan yang ingin dicapai, karena akan membuat masalah baru yang lebih fatal dan kompleks (Arafah et. al, 2018). Untuk itu, perlu dilakukan penelitian determinasi pertumbuhan ekonomi berkelanjutan di ASEAN-3. Hal ini, akan menunjang penyelesaian dalam mengatasi pertumbuhan ekonomi dengan menjaga kelestarian lingkungan, sehingga disamping masyarakat memperoleh peningkatan pendapatan juga mendapatkan penghidupan yang lebih baik.

\section{TINJAUAN PUSTAKA}

Kaum kapitalis yang menguasai perekonomian, menganggap bahwa pertumbuhan dan pembangunan ekonomi akan optimum, apabila semua faktor produksi digunakan secara baik dan merata, dengan memanfaatkan tenaga kerja yang ada, guna mengatasi pengangguran, sehingga pemanfaatan teknologi pertanian menjadi tidak berkembang (Ricardo, 1912). Para pelaku ekonomi, perlu memiliki jiwa entrepreneurship dalam mengembangkan ekonomi melalui inovasi, akan tetapi dengan semakin berkembangnya kemajuan perekonomian, juga akan berdampak pada keterbatasan inovasi (Shumpeter, 1934). Tabungan, populasi penduduk, dan teknologi dalam jangka panjang juga akan mempengaruhi pertumbuhan ekonomi (Solow, 1956). Tabungan serta investasi pun akan meningkatkan perekonomian (Domar, 1957).

Terdapat beberapa penelitian pertumbuhan ekonomi yang berkaitan dengan kelestarian lingkungan. Gylfalson dan Zoega (2006), dengan temuan bahwa semakin besar ketergantungan negara terhadap sumber daya alam, akan semakin terabaikannya dalam meningkatkan tabungan dan investasi. Gylfalson (2001), mengungkapkan adanya pengaruh negatif sumber daya alam terhadap pertumbuhan ekonomi. Atkinson dan Hamilton (2003), mengungkapkan bahwa kebijakan yang salah akan berdampak pada semakin rendahnya perhatian terhadap tabungan, sehingga pertumbuhan ekonomi menjadi terhambat. Nili dan Rastad (2007), berpendapat bahwa negara yang kaya akan minyak cenderung memiliki lebih rendah pembiayaan pembangunan dibandingkan dengan ekonomi negara berkembang yang tidak kaya minyak. Schembri et. al. (2015), menyatakan bahwa alasan untuk pertumbuhan hijau dan pembangunan bersih merupakan winwin solution bagi lingkungan dan 
Jurnal Ilmiah Ekonomi dan Bísnis

Vol. 16. No.2, September 2019: 176-182

EISSN : $2442-9813$

ISSN : $1829-9822$

pembangunan ekonomi. Shen (2015), dalam penelitian konseptualnya menjelaskan betapa penting hubungan antara kelestarian lingkungan dengan pembangunan ekonomi.

Sen (2014), dengan temuan dilakukannya pembangunan yang berkelanjutan, secara substansi akan meningkatkan pembangunan keseluruhan. Piseth (2013), mengungkapkan bahwa sumber daya alam memiliki kaitan yang positif dengan pertumbuhan ekonomi. Sachs dan Warner (1997), menemukan signifikan negatif hubungan antara ketergantungan sumber daya, rasio produk utama terhadap PDB. Husein dan Saidin (2012), mengungkapkan bahwa dari ke empat negara, yakni Malaysia, Indonesia, Thailand, dan Filipina, hanya di Indonesia yang PMA-nya signifikan positif terhadap pertumbuhan ekonomi, tetapi pembentukan modal tidak ada yang signifikan.

Pambudi dan Miyasto (2013), mengungkapkan investasi signifikan positif dengan pertumbuhan ekonomi. Asnawi dan Fitria (2018), menemukan bahwa inflasi signifikan negatif dengan pertumbuhan ekonomi. Bloom (2003), mengungkapkan ada yang pro dan kontra tentang korelasi pertumbuhan penduduk dengan berkembangnya pertumbuhan ekonomi. Kontra terjadi karena adanya fakta generasi baby boomer, justru membuat ekonomi menjadi overheated, karena tidak diimbangi dengan pertambahan luas lahan, ditambah lagi dengan terjadinya pergeseran dari adanya inovasi, yang berdampak pada padat karya menjadi padat modal.

Berdasarkan kajian teori dan studi empiris, maka peneliti membuat suatu kerangka pemikiran, dengan hipotesis inflasi, populasi penduduk, penipisan SDA masing-masing signifikan negatif dengan PDB per kapita, untuk pembentukan modal dan total tabungan masing-masing signifikan positif dengan PDB per kapita. Adapun kerangkanya, yakni:

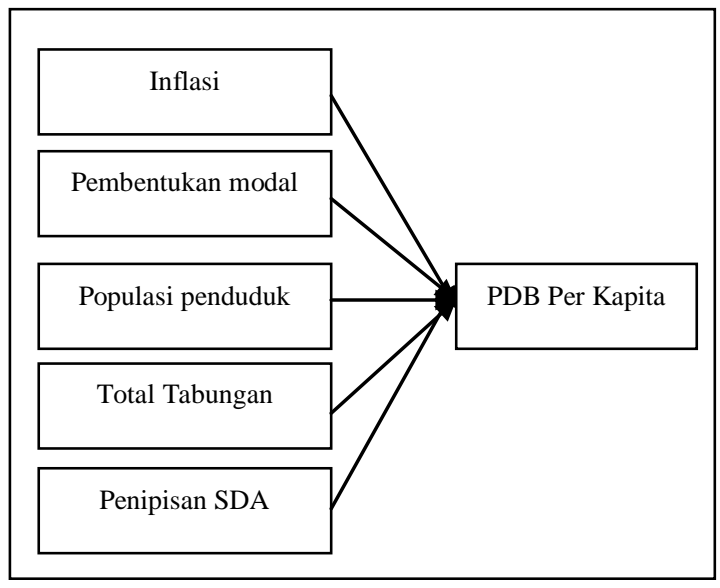

Gambar 2. Kerangka Pemikiran

\section{METODE PENELITIAN}

Data panel yang digunakan dalam penelitian ini dari tiga negara, yakni Malaysia, Filipina, dan Indonesia, pada 2000-2016, yang diperoleh dari IMF dan World Bank. Metode yang digunakan regresi data panel, dengan variabel bebas pembentukan modal, penipisan Sumber daya Alam, total tabungan, populasi penduduk, inflasi dan variabel terikatnya produk domestik bruto (PDB) per kapita. IHK digunakan untuk inflasi. Pembentukan modal merupakan tingkat pertumbuhan tahunan pembentukan modal bruto, berdasarkan mata uang lokal konstan pada 2000.

Tingkat penipisan SDA merupakan jumlah penipisan hutan bersih, penipisan energi, dan penipisan mineral. Penipisan hutan bersih dilihat dari sumber unit yang dikali dari kelebihan panen kayu selama masa pertumbuhan. Penipisan energi merupakan rasio nilai persediaan sumber energi hingga sisa masa pakai cadangan (dibatasi 25 tahun). Hal ini mencakup batubara, minyak mentah, dan gas alam. Penipisan mineral merupakan rasio nilai persediaan sumber daya mineral sampai sisa masa pakai cadangan (dibatasi 25 tahun). Hal ini mencakup timah, emas, 
timbal, seng, besi, tembaga, nikel, perak, bauksit, dan fosfat.

Total pertumbuhan populasi merupakan pertumbuhan populasi tahun $\mathrm{t}$, yang merupakan eksponensial pertumbuhan penduduk pertengahan tahun dari tahun t-1 sampai t. Total tabungan merupakan tingkat pertumbuhan tabungan nasional yang dimiliki ke tiga negara. PDB per kapita merupakan PDB dibagi populasi pertengahan tahun. Model yang digunakan:

$\begin{array}{lrl}\text { PDB per kapita } & =\beta_{0}+\beta_{1} \text { Inf }+\beta_{2} \mathrm{CF}+\beta_{3} \text { Pop } \\ & +\beta_{4} \text { Sav }+\beta_{5} \mathrm{NRD}+\varepsilon_{\mathrm{it}} \\ \text { Keterangan: } & \\ \text { PDB/kapita } & =\text { PDB per kapita (USD). } \\ \text { Inf } & =\text { Inflasi (Persen). } \\ \text { CF } & =\text { Pembentukan modal (Persen) } \\ \text { Pop } & =\text { Populasi penduduk (Persen). } \\ \text { Sav } & =\text { Total tabungan (Persen). } \\ \text { NRD } & =\text { Penipisan SDA (Persen). }\end{array}$

\section{HASIL DAN PEMBAHASAN}

Deskripsi variabel penelitian dari ketiga negara pada 2000-2016 mengalami fluktuasi. PDB per kapita rata-rata sebesar 3877,26 USD, dengan pendapatan tertinggi di Malaysia pada 2014 sebesar 11.1183,96 USD dan terandah di Indonesia pada 2001 sebesar 7747,98 USD. Pembentukan modal rata-rata sebesar 7,51 persen, terbesar pada 2009 sebesar 67,39 persen dan terkecil pada 2009 sebesar minus 17,94 persen, yang kesemuanya berada di Indonesia. Penipisan sumber daya alam terbesar di Indonesia pada 2000 sebesar 7,20 persen dan terkecil di Filipina pada 2001 sebesar 0,35 persen, dengan rata-rata sebesar 3,29 persen. Inflasi rata-rata sebesar 4,48 persen, dengan tertinggi di Indonesia pada 2006 sebesar 13,11 persen dan terendah di Malaysia pada 2009 sebesar 0,58 persen.

Populasi penduduk rata-rata sebesar 1,66 persen, yang tertinggi sebesar 2,31 persen di Malaysia pada 2000 dan terendah di Indonesia sebesar 1,14 persen pada 2016. Total tabungan rata-rata 24,24 persen, yang terbesar di Filipina yakni
37,36 persen pada 2010 dan terkecil di Malaysia sebesar 11,84 persen pada 2015 .

Penelitian menggunakan uji stasioneritas dengan metode Levin-Lin$\mathrm{Chu}$, guna mengukur tingkat stasioneritas dari masing-masing variabel secara bersama-sama. Hasil pengujian yang menunjukkan nilai minus dan $\mathrm{p}$-value lebih kecil dari $\alpha$ sebesar 5 persen, variabelnya stasioner. Uji stasioner Im-Pesaran-Shin digunakan untuk mengukur tingkat stasioneritas masing-masing variabel secara individu. Hal ini, dikarenakan peneliti memutuskan untuk melakukan dua uji yang dilakukan pada penelitian ini. Hasil uji diperoleh, semua variabel yang ada stasioner dengan tingkat level, baik dengan .menggunakan metode Levin-Lin-Chu, maupun dengan metode Im-Pesaran-Shin. Adapun hasil uji seperti pada Tabel 1.

Tabel 1. Pengujian Stasioneritas pada Level

\begin{tabular}{ccccc}
\hline \multirow{2}{*}{ Variabel } & \multicolumn{4}{c}{ Uji Stasioneritas } \\
\cline { 2 - 5 } & Levin-Lin-Chu & \multicolumn{2}{c}{ Im-Pesaran-Shin } \\
\cline { 2 - 5 } PDB/kapita & -0.4022 & 0.0438 & -1.2053 & 0.0141 \\
CF & -6.0064 & 0.0000 & -1.3145 & 0.0343 \\
NRD & -1.9048 & 0.0284 & -3.4450 & 0.0003 \\
Inf & -3.0338 & 0.0012 & -2.7399 & 0.0010 \\
Pop & -1.3875 & 0.0126 & -0.3458 & 0.0517 \\
Sav & -0.0685 & 0.0117 & -3.7684 & 0.0479 \\
\hline
\end{tabular}

Sumber: Data Hasil Olahan

Data yang stasioner, dapat diproses ke tahap berikutnya. Estimasi data panel, ada tiga model, yakni common effect, fixed effect, dan random effect. Untuk itu, perlu dilakukan uji, guna memilih model yang tepat. Tahap awal dilakukan uji Chow, yang berguna untuk memilih antara model common effect dengan fixed effect. Uji Chow terlihat dari nilai Prob $>F$ yang dihasilkan dari estimasi fixed effect.

Tabel 2. Perolehan Dari Uji Chow

\begin{tabular}{cccc}
\hline Metode & Probabilita & Keputusan & Keterangan \\
\hline Chow Test & 0.0029 & Ho ditolak & Fixed Effect \\
\hline
\end{tabular}

Sumber: Data Hasil Olahan

Hasil Prob>F tersebut adalah 0,0029 yang lebih rendah dari 0,05 , yang artinya model yang baik adalah fixed effect. Untuk 


\section{Jurnal Ilmiah Ekonomi dan Bisnis}

Vol. 16. No.2, September 2019: 176-182

EISSN : $2442-9813$

ISSN : $1829-9822$

itu, perlu dilakukan uji Hausman, guna membandingkan antara fixed effect dengan random effect.

Tabel 3. Hasil Tes Hausman

\begin{tabular}{cccc}
\hline Metode & $\begin{array}{c}\text { Probabilita } \\
\text { Chi-square }\end{array}$ & Keputusan & Keterangan \\
\hline Hausman Test & 0.0150 & Ho ditolak & Fixed Effect \\
\hline
\end{tabular}

Sumber: Data Hasil Olahan

Berdasarkan hasil tes Hausman, model fixed effect yang baik, karena nilai prob $>$ chi $^{2}$ lebih rendah dari 0,05 , yakni 0,0150. Dengan demikian, model yang digunakan dalam penelitian fixed effect.

Berdasarkan nilai estimasi untuk model secara agregat dari ketiga negara ASEAN, seperti pada tabel 4.

Tabel 4. Hasil Estimasi Agregat

\begin{tabular}{ccc}
\hline \multicolumn{3}{c}{ Variabel Dependen: PDB per Kapita } \\
\hline Variabel & Koefisien & p-value/2 \\
CF & 0.4135101 & $0.0015^{*}$ \\
NRD & -0.124592 & $0.0975^{* *}$ \\
Inf & -0.456641 & $0.0015^{*}$ \\
Pop & -0.00015 & $0.0975^{* *}$ \\
Sav & 0.00031 & $0.008^{*}$ \\
C & 4.836375 & 0.0000 \\
Prob. F-Stat & 0.0000 & \\
Adjusted ${ }^{2}$ & 0.477 & \\
\hline Keterangan: & &
\end{tabular}

Keterangan:

$*: \alpha=5$ persen.

$* *: \alpha=10$ persen.

Sumber: Data Hasil Olahan

Tabel 4, mengindikasikan secara agregat besar PDB per kapita di ketiga negara tersebut, secara signifikan dipengaruhi variabel independen. Kondisi tersebut, diketahui dari nilai Prob. Fstatistic dengan nilai signifikan sebesar 0,0000. Hasil penelitian juga menunjukkan bahwa kesemua variabel memiliki arah korelasi sesuai dengan teori. Dengan adjusted R-Squared 0,4770, yang menunjukkan kesemua variabel independen dapat menjelaskan terhadap perilaku variabel dependen sebesar 47,70 persen, untuk sisanya yang 52,3 persen, merupakan perilaku dari variabel independen lain yang tidak digunakan di dalam model.

Peningkatan pembentukan modal sebesar 1 persen, dari ke tiga negara ASEAN, akan meningkatkan PDB per kapitanya 0,4135101 persen, begitu pula sebaliknya, menurunnya pembentukan modal 1 persen, PDB per kapita ASEAN-3 akan menurun sebanyak 0,4135101 persen. Kondisinya sesuai teori dan signifikan, karena nilai $p$-value sebesar $0,0015<0,05$.

Sumber daya alam, yang dalam penelitian ini diproksikan dengan tingkat penipisan sumber daya alam terhadap PDB, ada pengaruh negatif dengan PDB per kapita di negara teraebut. Artinya, ada suatu nilai yang hilang, padahal seharusnya SDA merupakan suatu faktor penggerak untuk dapat meningkatkan pertumbuhan ekonomi. Pada tingkat penipisan SDA di negara ASEAN-3, naik 1 persen, PDB per kapita negara tersebut, mengalami penurunan 0,125459 persen, begitu pula sebaliknya. Kondisi ini, sesuai dengan teori dan signifikan, kerena nilai p-value sebesar $0,0975<0,1$.

Peningkatan populasi penduduk 1 persen di negara tersebut, PDB per kapita turun 0,00015 persen, dan sebaliknya. Peningkatan populasi sebesar 1 persen, besarnya PDB per kapita ASEAN-3 turun 0,00015 persen. Kondisinya sesuai teori dan signifikan, karena nilai p-value sebesar $0,0975<0,1$.

Negara ASEAN-3 dengan inflasi yang naik 1 persen, PDB per kapita ASEAN-3 turun 0,456641 persen, dan sebaliknya, menurunnya inflasi di negara ASEAN-3 sebesar 1 persen, maka PDB per kapita ASEAN-3 akan naik sebesar 0,456641 persen. Kondisi ini, sesuai dengan teori dan signifikan, karena nilai nilai $\mathrm{p}$ value sebesar $0,0015<0,05$.

Semakin besarnya total tabungan, akan meningkatkan PDB per kapita di negara ASEAN-3. Saat total tabungannya naik 1 persen, PDB per kapita meningkat 0,00031 persen, dan sebaliknya, saat nilai 
total tabungannya turun 1 persen, PDB per kapita turun 0,00031 persen. Kondisi ini, sesuai dengan teori dan signifikan, karena p-value $0,008<0,05$.

Terkait dengan upaya pertumbuhan PDB di ASEAN-3, terdapat beberapa sektor yang dapat dijadikan penyangga. Adapun sektor yang perlu dijaga kestabilannya guna menunjang PDB, pada sektor yang bergerak di bidang jasa dan infrastuktur. Namun demikian, keberhasilan peningkatan pertumbuhan ekonomi tergantung pada kemampuan dari masing-masing negara, dalam menjaga pertumbuhan konsumsi domestiknya. Disamping itu, ASEAN-3 perlu juga menjaga dan mengantisipasi perubahan ekonomi makro, yakni inflasi, kurs, distribusi pendapatan sesama anggota ASEAN.

Untuk kasus di Indonesia, agak unik, karena walaupun pertumbuhan ekonomi tinggi, namun masih dikatakan belum proposional, yang disebabkan sektor yang berkembang justru tidak signifikan dalam menyerap tenaga kerja.

Fokus dari penelitian ini, hanya mengunakan variabel ekonomi, sedangkan di dalam penelitian determinasi pertumbuhan ekonomi berkelanjutan, sebaiknya tidak hanya dilihat dari sektor ekonomi saja, tetapi juga memperhatikan variabel lain, seperti infrastruktur, kondisi tingkat kesejahteraan tenaga kerja buruh (baik upah buruh maupun kualitas atau produktivitas buruh), serta kestabilan politik. Disamping itu, perlu juga memperhatikan dengan semakin berkembangnya blok-blok perdagangan internasional.

\section{KESIMPULAN DAN SARAN}

Kesemua variabel independen signifikan dan sesuai dengan teori. Populasi penduduk, inflasi, penipisan sumber daya alam signifikan dan berpengaruh negatif dengan PDB per kapita, untuk pembentukan modal serta total tabungan signifikan dan berpengaruh positif dengan PDB per kapita. Oleh karena itu, perlu dilakukan inovasi dengan memanfaatkan teknologi.

Namun, yang perlu juga dipertimbangkan dalam pemanfaatan teknologi, menggunakan yang ramah terhadap lingkungan, serta jangan sampai bertabrakan dengan kepentingan manusia, terutama yang terkait dengan lapangan pekerjaan. Pihak ASEAN perlu meningkatkan daya tarik investasi dan peningkatan tabungan masyarakat, sumber daya manusia, kemampuan dalam mengantisipasi gejolak ekonomi makro berupa kurs dan inflasi, serta melakukan konsolidasi kerjasama intra dan ekstra ASEAN.

\section{DAFTAR PUSTAKA}

Arafah, Willy., Lucky Nugroho, Rowlan Takaya, Soeharjoto Soekapdjo, 2018. Marketing Strategy for Renewable Energy Development In Indonesia Context Today. International Journal of Energy Economics and Policy. Vol. 8(5).

Asnawi dan Hafizatul Fitria. 2018. Pengaruh Jumlah Uang Beredar, Tingkat Suku Bunga dan Inflasi Terhadap Pertumbuhan Ekonomi di Indonesia. Ekonomika Indonesia. Vol. 7(1).

Atkinson, Giles and Kirk Hamilton. 2003. Savings, Growth and the Resource Curse Hypothesis. World Development. Vol. 31(11).

Bloom, David., David Canning and Jaypee Sevilla. 2003. The Demographic Divident: A New Perspective on The Economic Consequences of Population Change. Santa Monika: RAND. 
Jurnal Ilmiah Ekonomi dan Bísnís

Vol. 16. No.2, September 2019: 176-182

EISSN : $2442-9813$

ISSN : $1829-9822$

Gunadi, Ariawan. 2016. ASEAN Economic Community Impact for Indonesia. Jurnal OPINIO JURIS. Vol. 19.

Gylfason, T., and G. Zoega. 2006. Natural Resources and Economic Growth: The Role of Investment. World Journal Economy, Vol. 29(8).

Gylfalson, T. 2001. Natural Resources, Education, and Economic Development. European Economic Review. Vol. 45(4).

Husein, Fauzi and Nooraini Saidin. 2012. Economic Growth in ASEAN-4 Countries: A Panel Data Analysis. International Journal of Economics and Finance. Vol. 4(9).

Nili, Masoud and Mahdi Rastad. 2007. Addressing the growth failure of the oil economies: The role of financial development. The Quarterly Review of Economics and Finance. Vol. 46(5).

Pambudi, Eko Wicaksono dan Miyasto. 2013. Analisis Pertumbuhan Ekonomi dan Faktor-Faktor yang Mempengaruhi (Kabupaten/Kota di Provinsi Jawa Tengah). Diponegoro Journal of Economics. Vol. 2(2).

Ricardo, David. 1912. The principles of political economy \& taxation. London, J. M. Dent \& sons, ltd.; New York, E. P. Dutton \& co

Soeharjoto. 2018. Kemampuan dan Kinerja Keuangan Provinsi Kalimantan. AKUNTABEL. Vol. 15(2).
Soeharjoto. 2016. Pengaruh Penanaman Modal Asing dan Tingkat Daya Saing Terhadap Ekspor Industri Manufaktur Indonesia. Media Ekonomi. Vol. 24(2).

Schembri, Patrick And Radja, Katia. 2015. Special Issue On Green Growth And Sustainability: New Challenges For An Economics Of Quality Int. J. Sustainable Development. Vol. 18. Nos. 1/2.

Sen, Salil K. 2014. Symbiotic linkage of sustainability, development and differentiation. Competitiveness Review. Vol. 24(2).

Sachs, Jeffrey D. and Andrew Warner. 1997. Sources of Slow Growth in African Economies. Journal of African Economies. Vol. 6(3).

Schumpeter J. 1934. Theory of Economic Development: An Inquiry into Profits, Capital, Credit, Interest, and the Business Cycle. Harvard University Press, Cambridge, MA

Solow, R. 1956. A Contribution to The Theory of Economic Growth, Quarterly Journal of Economics, Vol. 70(1).

Domar, Evsey. Essays in the Theory of Economic Growvth, Oxford University Press, 1957.

www3.weforum.org

www.world-economic-forum.org

www. wordbank.org

www.imf.org 